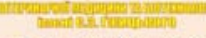

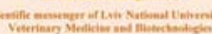

5. Whes:

10iring

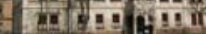

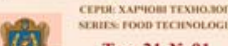

Науковий вісник Дьвівського національного університету ветеринарної медицини та біотехнологій імені С.3. Гжицького. Серія: Харчові технології

\author{
Scientific Messenger of Lviv National University
} of Veterinary Medicine and Biotechnologies.

Series: Food Technologies

ISSN 2519-268X print

https://nvlvet.com.ua/index.php/food

doi: $10.32718 /$ nvlvet-f9124

UDC 637.523

\title{
Assessment of organoleptic and functional-technological indices of truncated semi-finished products
}

\author{
I.I. Simonova ${ }^{1}$, L.V. Peshuk ${ }^{2}$ \\ ${ }^{1}$ Stepan Gzhytskyi National University of Veterinary Medicine and Biotechnologies Lviv, Ukraine \\ ${ }^{2}$ Education and Scientific Institute of Food Technologies, Kyiv, Ukraine
}

\section{Article info}

Received 07.02.2019

Received in revised form 11.03.2019

Accepted 12.03.2019

Stepan Gzhytskyi National University of Veterinary Medicine and Biotechnologies Lviv, Pekarska Str., 50, Lviv, 79010, Ukraine.

Tel::+38-096-484-69-9l

E-mail:ira.markovuch@gmail.com

Education and Scientific Institute of Food Technologies, Volodymyrska Str., 68, Kyiv, 01601, Ukraine.

Tel.:+38-098-582-88-36 E-mail: scorpion17lv@ukr.net
Simonova, I.I., \& Peshuk, L.V. (2019). Assessment of organoleptic and functional-technological indices of truncated semi-finished products. Scientific Messenger of Lviv National University of Veterinary Medicine and Biotechnologies. Series: Food Technologies, 21(91), 143-148. doi: $10.32718 /$ nvlvet-f9124

Manufacturing of chopped products of poultry meat and lentils is one of the promising areas of meat food production. The combination of animal and plant components allows to supplement the products with lacking biologically active substances and to obtain food products with a required chemical composition. In this respect, issues related to the investigation of the possibility to use lentil flour, maize grits in prefabricated poultry meat products, and the improvement of their technology are relevant. An analytical review of the literature was conducted, meat for processing was selected, new recipes of truncated semi-finished products using lentil flour, maize grits were developed, organoleptic parameters of truncated semi-finished products were determined, physicochemical and functional-technological properties of minced meat products of semi-finished raw and finished products were investigated. The main raw material for the production of semi-finished products is semi-lean pork, goose meat, chicken meat, sprouted lentil flour, maize grits for pre-dust and other components according to the developed formulation. Cutlets were taken as a control sample, its recipe include first grade beef, semi-lean pork, wheat flour bread, wheat bread wheat bread and other ingredients. According to the organoleptic evaluation of new types of minced semi-finished products, it was found that the best organoleptic properties had samples that included semi-lean pork and chicken meat, with addition of $8 \%$ of sprouted lentil flour and chicken meat, with the addition of $12 \%$ of lentil flour. It was revealed that meat and lentil flour cause the increase of the weight fraction of protein (16.91, $18.04 \%)$ in specimens number 1 and number 3. The moisture- and grease-retention capacity of the products is improved by the use of lentil flour and maize grits for pre-dust in samples No. 2 and No. 3.

Key words: goose meat, chicken, lentil, maize grits.

\section{Дослідження органолептичних та функціонально-технологічних показників посічених напівфабрикатів}

\author{
I.I. Сімонова ${ }^{1}$, Л.В. Пешук ${ }^{2}$ \\ ${ }^{1}$ Львівський національний університет ветеринарної медиџини та біотехнологій імені С.3. Гжиџького, \\ м. Львів, Україна \\ ${ }^{2}$ Навчально-науковий інститут харчових технологій, м. Київ, Украӥна
}

Одним з перспективних напрямків виробництва м'ясопродуктів є створення посічених фабрикатів з м'яса птиці та сочевиці. Поєднання тваринних і рослинних компонентів дозволить взаємно доповнити продукти відсутніми біологічно активними речовинами, отримати харчові продукти із заданим хімічним складом. У зв'язку з иим питання, пов'язані з вивченням можливості використання борошна сочевиці, крупи кукурудзяної у посічених напівфабрикатах з м'яса птиці, і удосконалення їх технологї є актуальним. Здійснено аналітичний огляд літератури, обрано м'ясну сировину, розроблено нові рецептури посічених напівфабрикатів з використанням борочна сочевиці, крупи кукурудзяної, визначено органолептичні показники посічених напівфабрикатів, досліджено фізико-хімічні та функціонально-технологічні властивості фаршів посічених напівфабрикатів сирих та готових виробів. Осно- 
вною сировиною для виробництва напівфабрикатів вибрано свинину напівжирну, м'ясо гусяче, м'ясо куряче, борошно пророщеної сочевиці, крупу кукурудзяну для панірування та інші компоненти згідно розробленої рецептури. За контрольний зразок взято котлети до рецептури яких входить яловичина жилована першого сорту, свинина напівжирна, хліб із пшеничного борошна, сухарі пшеничні для панірування та інші компоненти. За даними органолептичної оцінки нових видів посічених напівфабрикатів встановлено, шчо найкрашими органолептичними властивостями володіють зразки до складу яких входить свинина напівжирна та м'ясо курятини, з додаванням борочна сочевиці пророщеної у кількості 8\% та м'ясо курятини, з додаванням борошна сочевиці пророщеної у кількості 12\%. Встановлено, щу м'ясна сировини та борошно сочевиці впливає на збільшення масової частки білка (16,91, 18,04\%) у зразках № 1 та № 3. Покрашується волого - та жиро утримуюча здатність виробів за рахунок використання борошна сочевиці та кукурудзяної крупи для панірування у зразках № 2 та № 3 .

Ключові слова: м'ясо гусяче, куряче, сочевичя, крупа кукурудзяна.

\section{Вступ}

Сучасне сільське господарство, зокрема тваринництво, зазнає істотних труднощів розвитку. Тому виникають проблеми 3 надходженням та переробкою яловичини та свинини. Усунути дефіцит тваринного білка у харчуванні можливо за рахунок галузі птахівництва, яка дає високу продуктивність за короткий час.

Зацікавлення рослинними білками в аспекті виробництва харчових продуктів 3'явилося завдяки стрімкому науково-технічному прогресу в сфері виробництва продукції і новим напрямкам інтенсифікації процесів отримання продуктів харчування 3 вторинних ресурсів переробних галузей аграрно-промислового комплексу, нетрадиційних джерел сировини на базі природно-наукового потенціалу в галузі фундаментальної біології, фізичної хімії та технології (Garbowska et al., 2013).

Оскільки існує проблема дефіциту білка в раціоні харчування людини, у харчовій промисловості все частіше використовується нетрадиційна для харчування білкова сировина, яка надає харчовим продуктам необхідних технологічних, органолептичних властивостей та забезпечує покращення біологічної цінності виробів (Sumczynski et al., 2015; Souza et al., 2015; Caparros Megido et al., 2016).

У світовій практиці широке застосування в харчових цілях мають білки насіння сої (Peshuk et al., 2015; Sharma et al., 2016; Zhou et al., 2017; Kalenik et al., 2017; Ziegler et al., 2017). Однак у сої міститься значна кількість ізофлавоноїдів, котрі при споживанні людиною можуть спричинити гормональний дисбаланс та порушення роботи щитоподібної залози (Randulová et al., 2011). За умови використання сої слід враховувати й те, що протягом останніх років 3'явилася велика кількість генетично модифікованих організмів, котрі використовуються в якості продуктів харчування (Zdjelar et al., 2013). Виходячи з вищенаведеного матеріалу важливим питанням сьогодення $\epsilon$ вирішення проблеми отримання високоефективного та безпечного рослинного білка, джерелом якого виступає сочевиця.

У сочевиці, так само як і в сої, переважають водо- і солерозчинні фракції, при цьому кількісно водорозчинна фракція білків сочевиці перевершує аналогічну фракцію білків сої. Сочевиця багата вільними амінокислотами, у своєму складі містить глютамінову i аспарагінову кислоти, велику кількість тирозину (Telezhenko \& Atanasova, 2010; Peshuk et al., 2015; Bean, 2016; Shyam et al., 2017). За вмістом незамінних амінокислот практично не поступається сої, а за деякими незамінимими (валін, ізолейцин, аргінін) навіть перевершує іiï (D'Mello, 2015). При пророщуванні їх кількість значно зростає (Markovych, 2014; Drachuk et al., 2018).

Використання борошна сочевиці, як компонента рецептур м'ясних виробів, дозволяє отримати фаршеві системи 3 високою емульгуючою здатністю, а готові продукти 3 - меншою кількістю жиру (Lukianchenko \& Avanesova, 2009).

Крім цього в останні роки лікарі почали все частіше діагностувати різні форми реакцій на глютенвмісні продукти, тому знання правил формування агліадинового раціону при збереженні всіх принципів раціонального харчування стає актуальним (Telezhenko \& Atanasova, 2013; Peshuk et al., 2015).

Пшениця, рис та кукурудза - це найбільш вживані зернові продукти у світі. Допустимий вміст глютену в натуральних продуктах харчування повинен становити менше 20 мг/кг. До продуктів, які позбавлені глютену, належать безглютенові крупи, а саме кукурудза, рис, гречка, пшоно (Aziz et al., 2015).

Метою роботи є підбір компонентів, розробка рецептур та дослідження споживчих властивостей посічених напівфабрикатів з використанням вище згаданої сировини.

Основними завданнями є:

1. Дослідити вплив різної кількості м'яса птиці, борошна сочевиці, крупи кукурудзяної на органолептичні показники посічених напівфабрикатів

2. Дослідити поєднання різної м'ясної та рослинної сировини на фізико-хімічні, структурно механічні та функціонально-технологічні показники напівфабрикатів до та після термічної обробки.

\section{Матеріал і методи досліджень}

Об'єкти досліджень - м'ясо гусяче та куряче, борошно сочевиці пророщеної, крупа кукурудзяна.

При проведені досліджень вивчено можливість заміни у складі рецептури посічених напівфабрикатів м'яса яловичини на м'ясо свинини, гуски, курки, хліба із пшеничного борошна на борошно сочевиці пророщеної, а у якості панірування використано замість сухарів пшеничних крупу кукурудзяну. Із дослідних рецептур вилучено меланж та сало не солене. Збільшено кількість цибулі ріпчастої з 2 до 4 кг на 100 кг, 3 метою покращення органолептичних показників напівфабрикатів. Кількість доданої солі та перцю чорного не змінено. 
За контрольний зразок взято котлети, до рецептури яких входить яловичина жилована першого сорту, свинина напівжирна, хліб із пшеничного борошна, сухарі пшеничні для панірування. Приготування посічених напівфабрикатів проведено згідно з загальною технологією.

У дослідних зразках посічених напівфабрикатів дослідження органолептичних та фізико-хімічних показників здійснювали за ДСТУ 4823.2:2007. Частина 2. Загальні вимоги. Продукти м'ясні. Органолептичне оцінювання показників якості (DSTU 4823.2:2007, 2008); ДСТУ ISO 1443:2005 ISO
1443:1973, IDT, М'ясо та продукти м'ясні. Метод визначення загального вмісту жиру (ISO 1443:1973, IDT) (DSTU ISO 1443:2005, 2007), ДСТУ ISO 1442:2005. М'ясо та продукти м'ясні. Метод визначення вмісту вологи (контрольний метод) (DSTU ISO 1442:2005, 2007), ДСТУ ISO 1841-2:2004 ISO 18412:1996, IDT. М'ясо та продукти м'ясні. Метод визначення вмісту хлоридів. Частина 2. Потенціометричний метод (DSTU ISO 1841-2:2004, 2005) у відповідності до ДСТУ 4437:2005 “Напівфабрикати м'ясні та м'ясорослинні посічені. Технічні умови” (DSTU 4437:2005, 2006).

\section{Таблиця 1}

Рецептури посічених напівфабрикатів, кг/100 кг

\begin{tabular}{lccccc}
\hline \multicolumn{1}{c}{ Найменування сировини } & Контроль & №1 & №2 & №3 & №4 \\
\hline Яловичина жилована першого сорту & 36,00 & - & - & - & - \\
Свинина напівжирна & 20,7 & 30 & - & - & 25 \\
М'ясо гусяче & - & - & 59,7 & - & 29,7 \\
М'ясо куряче & - & 30 & - & 59,7 & - \\
Меланж & 1,0 & - & - & - & - \\
Сало несолене & 2,0 & - & - & - & - \\
Цибуля ріпчаста свіжа & 2,0 & 4,0 & 4,0 & 4,0 & 4,0 \\
Борошно сочевиці пророщеної & - & 8 & 12 & 10 & 12 \\
Вода для гідратації & 20 & 20 & 20 & 20 & 20 \\
Сухарі пшеничні для панірування & 4 & - & 2 & - & - \\
Кукурудзяна крупа для панірування & - & 2 & - & 2 & 4 \\
Хліб із пшеничного борошна & 13,0 & - & - & - & - \\
Сіль кухонна & 1,2 & 1,2 & 1,2 & 1,2 & 1,2 \\
Перець чорний мелений & 0,1 & 0,1 & 0,1 & 0,1 & 0,1 \\
\hline
\end{tabular}

Структурно механічні та функціональнотехнологічні показники напівфабрикатів за стандартними методиками (Antypova et al., 2001).

Абсолютну похибку вимірювання визначали за критерієм Ст'юдента, $\mathrm{M} \pm 0,97, \mathrm{n}=5$.

\section{Результати та їх обговорення}

Оцінку органолептичних показників проводи дегустаційною комісією на кафедрі технології м'яса i м'ясних та олійно-жирових виробів Львівського національного університету ветеринарної медицини та біотехнологій імені С.3. Гжицького.

Серед показників, які оцінено були зовнішній вигляд, а саме округло-приплюснутої форми, поверхня напівфабрикатів рівномірно посипана панірувальням, вигляд на розрізі - рівномірно перемішаний, від тем- но-червоного до світло-рожевого кольору, консистенція - у смаженому вигляді соковита, не крихка, смак і запах до термічної обробки - властиві доброякісній сировині і спеціям, після термічної обробки - властивий даному продукту, без стороннього присмаку, запаху. За результатами проведеної дегустації визначено органолептичну оцінку напівфабрикатів і вибрано найкращі зразки.

Результати таблиці 2 дають можливість стверджувати, що вироби отримані 3 додаванням борошна сочевиці пророщеної, мають приємний аромат, привабливий зовнішній вигляд та добрий смак. У рецептурі №4 3 комбінацією гусячого м'яса та свинини присутній явно виражений після смак борошна сочевиці, що і є причиною низької загальної органолептичної оцінки.

Таблиця 2

Органолептична оцінка січених напівфабрикатів

\begin{tabular}{c|c|c|c|c|c|c|c}
\hline \multirow{2}{*}{$\begin{array}{c}\text { Посічені } \\
\text { напівфабрикати }\end{array}$} & $\begin{array}{c}\text { Зовнішній } \\
\text { вигляд }\end{array}$ & Форма & Смак & Запах & $\begin{array}{c}\text { Консис- } \\
\text { тенція }\end{array}$ & $\begin{array}{c}\text { Вигляд на } \\
\text { розрізі }\end{array}$ & $\begin{array}{c}\text { Загальна } \\
\text { оцінка }\end{array}$ \\
\hline Контроль & $4,4 \pm 0,1$ & $5,0 \pm 0,2$ & $5,0 \pm 0,1$ & $5,0 \pm 0,1$ & $4,8 \pm 0,2$ & $4,7 \pm 0,1$ & 4,82 \\
Рецептура №1 & $5,0 \pm 0,2$ & $5,0 \pm 0,2$ & $4,6 \pm 0,1$ & $5,0 \pm 0,1$ & $4,8 \pm 0,2$ & $4,9 \pm 0,2$ & 4,98 \\
Рецептура №2 & $5,0 \pm 0,1$ & $5,0 \pm 0,1$ & $4,8 \pm 0,2$ & $5,0 \pm 0,2$ & $5,0 \pm 0,1$ & $5,0 \pm 0,2$ & 4,86 \\
Рецептура№3 & $5,0 \pm 0,1$ & $5,0 \pm 0,2$ & $4,9 \pm 0,1$ & $5,0 \pm 0,1$ & $5,0 \pm 0,1$ & $5,0 \pm 0,2$ & 4,98 \\
Рецептура №4 & $5,0 \pm 0,2$ & $5,0 \pm 0,1$ & $4,8 \pm 0,2$ & $4,2 \pm 0,1$ & $4,2 \pm 0,1$ & $4,7 \pm 0,1$ & 4,58 \\
\hline
\end{tabular}

Примітка: $\mathrm{M} \pm 0,97, \mathrm{n}=5$ 
Найвищу оцінку отримали напівфабрикати до складу яких входить м'ясо курятини та борошно сочевиці пророщеної у кількості 8 та 10\%. Кукурудзяна крупа, використана для панірування, надає виробам гарного кольору, приємного смаку.

При виготовленні м'ясних виробів необхідно враховувати не лише органолептичні, але і їх фізикохімічні, структурно-механічні та функціональнотехнологічні показники.

\section{Таблиця 3}

Фізико-хімічні показники посічених напівфабрикатів охолоджених

\begin{tabular}{cccccc}
\hline Варіанти рецептур & Білки, \% & Жири, \% & Волога, \% & Зола, \% & $\begin{array}{c}\text { Кухонна } \\
\text { сіль, \% }\end{array}$ \\
\hline Контроль & $16,64 \pm 0,1$ & $4,22 \pm 0,1$ & $65,5 \pm 0,2$ & $1,60 \pm 0,1$ & $1,28 \pm 0,2$ \\
№1 & $16,91 \pm 0,1$ & $7,53 \pm 0,1$ & $69,6 \pm 0,2$ & $2,37 \pm 0,1$ & $1,25 \pm 0,2$ \\
№2 & $15,91 \pm 0,1$ & $9,85 \pm 0,1$ & $65,8 \pm 0,2$ & $2,18 \pm 0,1$ & $1,24 \pm 0,1$ \\
№3 & $18,04 \pm 0,1$ & $3,49 \pm 0,2$ & $67,2 \pm 0,1$ & $2,48 \pm 0,1$ & $1,26 \pm 0,2$ \\
\hline
\end{tabular}

Примітка: $\mathrm{M} \pm 0,97, \mathrm{n}=5$

У рецептурах № 1 вміст білка збільшується у порівнянні із контролем за рахунок додавання борошна сочевиці пророщеної, які у своєму складі містять більше білка. Рецептура № 2 містить м’ясо гусяче, яке в порівнянні з контролем містять менше білку та більше жиру ніж яловичина в контрольному зразку. Вміст білка збільшується за рахунок використання у рецептурі борошна пророщеної сочевиці у кількості 12\%. До складу рецептури № 3 входить м'ясо куряче та борошно сочевиці пророщеної, у кількості 10\%, що містить більше білку ніж м'ясо яловиче у контролі.

Вміст жиру та вологи для даного виду продукту відповідає вимогам ДСТУ 4437:2005. Згідно 3 яким масова частка вологи повинна становити не більше $70 \%$, а жиру не більше 18\%. Відмінності в кількісних
Важливим є дослідження поєднання різної м'ясної сировини, а саме м'яса птиці (гусячого та курячого) зі свининою в заданому співвідношенні та вплив борошно пророщеної сочевиці на фізико-хімічні, структурно механічні та функціонально-технологічні показники розроблених продуктів.

Фізико-хімічні показники посічених напівфабрикатів охолоджених наведено у таблиці 3.

\section{Таблиця 4}

Функціонально-технологічні та структурно-механічні показники посічених напівфабрикатів охолоджених

\begin{tabular}{|c|c|c|c|c|c|c|}
\hline $\begin{array}{l}\text { Варіанти } \\
\text { рецептур }\end{array}$ & $\begin{array}{c}\text { Вміст зв'язаної } \\
\text { вологи, \% до } \\
\text { маси м'яса } \\
\end{array}$ & $\begin{array}{c}\text { Вміст зв’язаної } \\
\text { вологи, \% до } \\
\text { загальної вологи }\end{array}$ & $\begin{array}{c}\text { Пласти- } \\
\text { чність, } \mathrm{cm}^{2} / \Gamma\end{array}$ & $\begin{array}{c}\text { Вологоут- } \\
\text { римуюча здат- } \\
\text { ність, \% } \\
\end{array}$ & $\begin{array}{c}\text { Жироут- } \\
\text { римуюча здат- } \\
\text { ність, \% } \\
\end{array}$ & Вихід, \% \\
\hline Контроль & $62,7 \pm 0,2$ & $77,9 \pm 0,1$ & $14,5 \pm 0,1$ & $89,5 \pm 0,1$ & $17,6 \pm 0,1$ & 108,6 \\
\hline №1 & $61,1 \pm 0,2$ & $76,5 \pm 0,2$ & $12,6 \pm 0,3$ & $82,7 \pm 0,1$ & $14,1 \pm 0,1$ & 143,6 \\
\hline №2 & $60,5 \pm 0,2$ & $74,2 \pm 0,1$ & $13,4 \pm 0,4$ & $86,3 \pm 0,1$ & $16,5 \pm 0,2$ & 145,5 \\
\hline №3 & $63,1 \pm 0,1$ & $79,7 \pm 0,1$ & $13,9 \pm 0,2$ & $87,1 \pm 0,1$ & $15,8 \pm 0,1$ & 146,6 \\
\hline
\end{tabular}

Примітка: $\mathrm{M} \pm 0,97, \mathrm{n}=5$

показниках жиру пояснюються різним видом м'яса в розроблених рецептурах. Вміст вологи вищий у порівнянні $з$ контролем. Це пояснюється тим, що гідратацію для продуктів переробки зернових проведено при гідромодулі 1:4. Вміст золи коливається в межах 2,182,48 , що вище показників контролю через те, що в сочевиці міститься від 2 до 4,4\% золи, для порівняння у м'ясі $0,9-1,0 \%$. $\mathrm{pH}$ розроблених рецептур становить $6,82-6,9$, у контрольному зразку 6,61 .

3 функціонально-технологічних та структурномеханічних показників посічених напівфабрикатів досліджено вміст зв'язаної вологи, пластичність, волого- та жироутримуючу здатності, вихід. Результати наведено у таблиці 4.

Таблиця 5

Фізико-хімічні показники посічених напівфабрикатів після термічної обробки

\begin{tabular}{ccccccc}
\hline $\begin{array}{c}\text { Варіанти } \\
\text { рецептур }\end{array}$ & Білки, \% & Жири, \% & Волога, \% & Зола, \% & $\begin{array}{c}\text { Кухонна } \\
\text { сіль, \% }\end{array}$ & $\mathrm{pH}$ \\
\hline Контроль & $15,86 \pm 0,07$ & $5,34 \pm 0,1$ & $49,6 \pm 0,1$ & $2,01 \pm 0,1$ & $1,32 \pm 0,2$ & $6,67 \pm 0,9$ \\
№ 1 & $16,05 \pm 0,08$ & $4,78 \pm 0,1$ & $53,4 \pm 0,2$ & $3,12 \pm 0,1$ & $1,51 \pm 0,1$ & $6,95 \pm 0,8$ \\
№ 2 & $15,12 \pm 0,08$ & $9,36 \pm 0,2$ & $52,9 \pm 0,1$ & $2,96 \pm 0,1$ & $1,48 \pm 0,2$ & $6,89 \pm 0,8$ \\
№ 3 & $17,35 \pm 0,06$ & $11,56 \pm 0,1$ & $49,2 \pm 0,1$ & $3,06 \pm 0,1$ & $1,52 \pm 0,2$ & $6,95 \pm 0,6$ \\
\hline Принтка
\end{tabular}

Пластичність у розроблених зразках становить $11,9-13,5 \mathrm{~cm}^{2} / \Gamma$, в контрольному зразку $14,7 \mathrm{~cm}^{2} / \Gamma$. Важливими показниками якості продукції є значення водоутримуючої (ВУЗ), жироутримуючої здатністі (ЖУЗ), які залежать від взаємодії білків між собою, 3 водою, від ступеня подрібнення м'ясної системи. 
При тепловій обробці посічених напівфабрикатів відбувається розм'якшення продукту, зміни форми, об'єму, маси, кольору, харчової цінності, формування смаку та аромату, зміни структурно-механічних характеристик.

Втрати маси після термічної обробки напівфабрикатів характерні для усіх дослідних зразків, проте, контрольний зразок, більш інтенсивно втрачає вологу (в середньому на 8\%) ніж у дослідних зразках. Це впливає за зміну органолептичних показників (консистенцію та соковитість).

У зв'язку з цим теплова обробка вагомо впливає на ці показники, а отже і на вихід готових виробів. Ви- користання кукурудзяної крупи у якості панірування запобігає втратам вологи у посічених напівфабрикатах.

Вміст вологи після термічної обробки зменшився у всіх рецептурах. Зростання вмісту золи при термічній обробці пояснюється збільшенням концентрації мікроелементів внаслідок зменшенням вмісту вологи в готовому продукті. Вміст солі збільшився за рахунок виділення вологи. рН збільшився і становить 6,896,96 в розроблених рецептурах, 6,67 в контрольному зразку.

\section{Таблиця 6}

Функціонально-технологічні та структурно-механічні показники посічених напівфабрикатів після термічної обробки

\begin{tabular}{ccccc}
\hline \multirow{2}{*}{ Варіанти рецептур } & $\begin{array}{c}\text { Вміст зв'язаної вологи, \% Вміст зв’язаної вологи, \% } \\
\text { до маси м’яса }\end{array}$ & $\begin{array}{c}\text { Пластич-ність, } \\
\text { до загальної вологи }\end{array}$ & \multirow{2}{*}{ Вихід, \% } \\
\hline Контроль & $54,8 \pm 0,1$ & $86,8 \pm 0,15$ & $7,1 \pm 0,19$ & 98,6 \\
№ 1 & $60,5 \pm 0,2$ & $84,5 \pm 0,19$ & $6,8 \pm 0,18$ & 120,4 \\
№ 2 & $52,1 \pm 0,2$ & $85,2 \pm 0,16$ & $6,2 \pm 0,21$ & 122,1 \\
№ 3 & $63,1 \pm 0,1$ & $87,1 \pm 0,16$ & $6,9 \pm 0,20$ & 122,5 \\
\hline
\end{tabular}

Примітка: $\mathrm{M} \pm 0,97, \mathrm{n}=5$

Заміна у рецептурах яловичини жилованої першого сорту на м'ясо гусяче і куряче, а меланж, сала несоленого та хліба із пшеничного борошна на борошно сочевиці пророщеної, використаної у різних співвідношеннях, а також використання крупи кукурудзяної для панірування замість сухарів пшеничних для панірування дозволить покращити не тільки органолептичні показники, але і надати виробам стабільних функціонально-технологічних властивостей, здешевити собівартість посічених напівфабрикатів.

\section{Висновки}

1. За даними органолептичної оцінки нових видів січених напівфабрикатів встановлено, що найкращими органолептичними властивостями характеризуються зразки № 1 та № 3. Для подальших досліджень відібрано зразки № 1-3.

2. При досліджені фізико-хімічних показників виробів встановлено, що на збільшення масової частки білка впливає використання м'ясної сировини (м'яса свинини, гусячого та курячого). Поєднання іiі 3 борошном сочевиці пророщеної призводить до збільшення масової частки білка у зразку № 3 до $18 \%$. Покращення функціонально-технологічних та структурно-механічних показників січених напівфабрикатів відбувається за рахунок використання у їх рецептурі борошна пророщеної сочевиці та у якості панірування - крупи кукурудзяної.

\section{References}

Garbowska, B., Radzymińska, M., \& Jakubowska, D. (2013). Influence of the origin on selected determinants of the quality of pork meat products. Czech
J. Food Sci, 31, 547-552. doi: 10.17221/479/2012CJFS.

Sumczynski, D., Bubelova, Z., Sneyd, J., Erb-Weber, S., \& Mlcek, J. (2015). Total phenolics, flavonoids, antioxidant activity, crude fibre and digestibility in nontraditional wheat flakes and muesli. Food Chem, 174, 319-325. doi: 10.1016/j.foodchem.2014.11.065.

Souza, P.M., Bittencourt, M.L., Caprara, C.C., et al. (2015). A biotechnology perspective of fungal proteases. Braz J Microbiol, 46(2), 337-346. doi: 10.1590/S1517-838246220140359.

Caparros Megido, R., Alabi, T., Nieus, C., et al. (2016). Optimisation of a cheap and residential small-scale production of edible crickets with local by-products as an alternative protein-rich human food source in Ratanakiri Province. Cambodia. J. Sci. Food Agric, 96(2), 627-632. doi: 10.1002/jsfa.7133.

Peshuk, L.V., Hashchuk, O.I., \& Moskaliuk, O.Ie. (2015). Innovatsiinyi miasnyi produkt. Kharchova promyslovist, 17, 64-67 (in Ukrainian).

Sharma, J.G., Kumar, A., Saini, D. Targay, N.L., Khangembam, B.K., \& Chakrabarti, R. (2016). In vitro digestibility study of some plant protein sources as aquafeed for carps Labeo rohita and Cyprinus carpio using pH-Stat method. Indian J. Exp. Biol., 54(9), 606611. https://www.ncbi.nlm.nih.gov/pubmed/28699726.

Zhou, J., Liu, J., \& Tang, X. (2017). Effects of whey and soy protein addition on bread rheological property of wheat flour. J. Texture Stud, 4, 20. doi: $10.1111 /$ jtxs. 12275 .

Kalenik, T.K., Costa, R., Motkina, E.V., et al. (2017). Technology development of protein rich concentrates for nutrition in extreme conditions using soybean and meat by-products. Acta Sc.i Pol. Technol. Aliment, 16(3), 255-268. doi: 10.17306/J.AFS.0501. 
Ziegler, V., Ferreira, C.D., Hoffmann J.F. et al. (2017). Effects of moisture and temperature during grain storage on the functional properties and isoflavone profile of soy protein concentrate. Food Chem., 242(1), 3744. doi: 10.1016/j.foodchem.2017.09.034.

Randulová, Z., Tremlová, B., Řezáčová-Lukášková, Z., Pospiech, M., \& Straka, I. (2011). Determination of soya protein in model meat products using image analysis. Czech J. Food Sci., 29, 318-321. doi: 10.17221/167/2015-CJFS.

Zdjelar, G., Nikolić, Z., Vasiljević, I., Bajić, B., Jovičić, D., Ignjatov, M., \& Milošević, D. (2013). Detection of genetically modified soya, maize, and rice in vegetarian and healthy food products in Serbia. Czech J. Food Sci, 31, 43-48. doi: 10.17221/105/2012-CJFS.

Telezhenko, L.M., \& Atanasova, V.V. (2010). Sochevytsia yak vazhlyvyi natsionalnyi resurs bilka. Kormy i kormovyrobnytstvo, 66, 158-163 (in Ukrainian).

Bean, A. (2016). The Vegetarian Athlete's Cookbook: More Than 100 Delicious Recipes. Active Living Bloomsbury Publishing.

Shyam, S., Yadav, McNeil, D., \& Philip, C. (2017). Stevenson Lentil: An Ancient Crop for Modern Times Springer Science \& Business Media.

Hrehircha, N.M., Peshuk, L.V., \& Zusko, K.V. (2017), Doslidzhennia sosysok z vkliuchenniam kvertsetynu i natyvnoi kvertsetynvmisnoi syrovyny podovzhenoho terminu zberihanni. Naukovi pratsi NUKhT, 23(4), 223-230 (in Ukrainian).

D'Mello, P.F. (2015). Amino Acids in Higher Plants. CABI.

Markovych, I.I. (2014). Doslidzhennia Aminokyslotnoho Skladu Napivkopchenykh Kovbas Z Vykorystanniam Sochevytsi Yalivtsiu Ta Chebretsiu. Skhidnoievropeiskyi Zhurnal Peredovykh Tekhnolohii, 6/10(72), 38-44. doi: 10.15587/1729-4061.2014.28725 (in Ukrainian).

Drachuk, U., Simonova, I., Halukh, B., Basarab, I., \& Romashko, I. (2018). The study of lentil flour as a raw material for production of semi-smoked sausages. Eastern-european journal of enterprise technologies, 6/11 (96), 44-50. doi: 10.15587/1729-
4061.2018.148319.

Lukianchenko, N.P., \& Avanesova, A.V. (2009). O Tseleobraznosty Prymenenyia Rostkov Proroshchennoi Chechevytsy Pry Proyzvodstve Miasnykh Polufabrykaov. Miasnoe Delo, 10, 24-25 (in Russian).

Telezhenko, L.M., \& Atanasov, V.V. (2013). Obhruntuvannia Tekhnolohichnykh Pidkhodiv Kompleksnoi Pererobky Sochevytsi. Kharchova Nauka I Tekhnolohiia, 4(25), 77-80 (in Russian).

Moskaluyk, O., Haschuk, A., \& Peshuk, L. (2015). Technology of meat loaves using cultivated mushroom. Scientific Messenger of LNU of Veterinary Medicine and Biotechnologies. Series: Food Technologies, 14(1), 6568. https://cyberleninka.ru/article/v/tehnologiyamyasnyh-hlebov-s-ispolzovaniem-kultiviruemyhgribov.

Aziz, I., Branchi, F., \& Sanders, D.S. (2015). The rise and fall of gluten! Proceedings Nutr. Society, 74, 221226. doi: $10.1017 / \mathrm{S} 0029665115000038$.

DSTU 4823.2:2007 (2008). Chastyna 2. Zahalni vymohy. Produkty miasni. Orhanoleptychne otsiniuvannia pokaznykiv yakosti. Kyiv, Derzhspozhyvstandart Ukrainy, 28 (in Ukrainian).

DSTU ISO 1443:2005ISO 1443:1973, IDT (2007). Miaso ta produkty miasni. Metod vyznachennia zahalnoho vmistu zhyru (ISO 1443:1973, IDT). Kyiv, Derzhspozhyvstandart Ukrainy, 17 (in Ukrainian).

DSTU ISO 1442:2005 (2007). Miaso ta produkty miasni. Metod vyznachennia vmistu volohy (kontrolnyi metod). Kyiv, Derzhspozhyvstandart Ukrainy, 20 (in Ukrainian).

DSTU ISO 1841-2:2004 ISO 1841-2:1996, IDT (2005). Miaso ta produkty miasni. Metod vyznachennia vmistu khlorydiv. Chastyna 2. Potentsiometrychnyi metod (ISO 1841-2:1996, IDT). Kyiv, Derzhspozhyvstandart Ukrainy, 15 (in Ukrainian).

DSTU 4437:2005 (2006). Napivfabrykaty miasni ta miaso-roslynni posicheni. Tekhnichni umovy. Kyiv, Derzhspozhyvstandart Ukrainy, 24 (in Ukrainian).

Antypova, L.V., Hlotova, Y.A., \& Rohov, Y.A. (2001). Metody issledovanyia miasa y miasnykh produktov. Moskva. Kolos (in Russian). 